\title{
Perancangan Website Program Studi Sistem Informasi Institut Informatika Dan Bisnis Darmajaya Bandar Lampung
}

\author{
Neni Purwati ${ }^{1}$, Halimah $^{2}$, Agus Rahardi ${ }^{3}$ \\ ${ }^{1}$ Program Studi Sistem Informasi Institut Informatika dan Bisnis Darmajaya \\ ${ }^{2}$ Program Studi Sistem Informasi Institut Informatika dan Bisnis Darmajaya \\ ${ }^{3}$ Program Studi Sistem Informasi Institut Informatika dan Bisnis Darmajaya \\ ${ }^{1}$ nenipurwati87@gmail.com \\ 2halimahyunus@darmajaya.ac.id \\ 3agusrahardi@darmajaya.ac.
}

\begin{abstract}
Informatics \& Business Institute (IBI) Darmajaya is a private university that prioritizes thr implementation of information technology advancement and business. The information system study program is one of the major in this campus. However, it did not have service facilities that eased the students, alumni and lecturers to gain information abaut the information system. The system development method used in the study was RUP (Rational Unified Process) to be used at the system development with these phases : Inception, Elaboration, Construction and Transition. One the website of the information system study program of IIB Darmajaya Bandar Lampung obtained and proposed would ease the study program of information system to give information to the students, alumni, and lecturers. Tthe data security was wholly managed by administration of information system study program. All information availabel on the website of the study program of information system was inputted into the database, so the problem in inputting faults would be established.
\end{abstract}

Keyword: Website; Study Program of Information System; RUP Method.

\begin{abstract}
Abstrak
Institut Informatika \& Bisnis (IIB) Darmajaya merupakan perguruan tinggi yang mengedepankan penerapan teknologi informasi dan bisnis. Prodi Sistem Informasi (SI) merupakan salah satu prodi yang terdapat di IIB Darmajaya, tetapi belum memiliki fasilitas layanan yang memudahkan mahasiswa, alumni dan dosen untuk memperoleh informasi terkait prodiSI tersebut. Metode pengembangan sistem yang digunakan adalah metode RUP (Rational Unified Process). Pada website SI yang dihasilkan memudahkan prodi SI untuk memberikan informasi kepada mahasiswa, alumni dan dosen. Keamanan data sepenuhnya dipegang oleh admin prodi (SI). Semua informasi yang ada di website prodi (SI) diinputkan didalam database, sehingga masalah kesalahan penginputan informasi dapat diatasi.
\end{abstract}

Kata Kunci : Website; Prodi SI; Metode RUP

\section{PENDAHULUAN}

IIB Darmajaya merupakan perguruan tinggi yang mengedepankan penerapan teknologi informasi dan bisnis. Dalam beberapa bidang sudah menerapkan teknologi informasi tersebut itu terbukti dengan adanya website-website seperti website IIB Darmajaya, website Informasi Akademik (SISKA), website Tugas Akhir (SISTA), website Internasional Office, website ICT, website IAC, akan tetapi tidak semua bagian di IIB Darmajaya memiliki fasilitas atau website yang berguna memberikan informasi terkait bagian tersebut kepada mahasiswa atau bagian lainnya. Salah satu bagian penting di IIB Darmajaya yang belum memiliki fasilitas atau website adalah Prodi SI. Saat ini Prodi SI hanya mengandalkan fasilitas papan pengumuman untuk menyampaikan informasi kepada mahasiswa, alumni dan dosen. Hal ini membuat penyampaian informasi masih belum optimal dengan keterbatasan penyampaian 
informasinya, karena belum terdapatnya media untuk menampung informasi Prodi SI IIB Darmajaya Bandar Lampung.

\section{KERANGKA TEORI}

\subsection{Metode Rational Unified Process (RUP)}

Menurut Rosa A.S dan M.Shalahuddin (2013,p.124) Unified Process atau di kenal juga proses iteratif dan incremental merupakan sebuah proses pengembangan perangkat lunak yang dilakukan secara iteratif (berulang) dan incremental (bertahap dengan proses menaik). Iteratif bisa dilakukan di dalam setiap tahap, atau iteratif tahap proses pengembangan perangkat lunak untuk menghasilkan perbaikan fungsi yang inkremental (bertambah menaik) di mana setiap iterasi akan memperbaiki iterasi berikutnya. Salah satu unified process yang terkenal adalah RUP (rational unified process). Berikut Phase RUP yang digunakan :

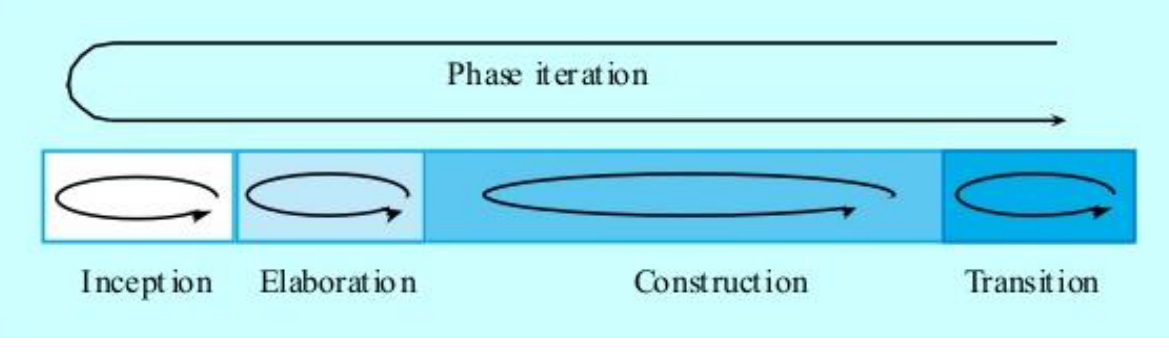

Gambar 1 Phase RUP (rational unified process)

\section{Inception (Permulaan)}

Tahap ini lebih pada pemodelan proses bisnis yang dibutuhkan (business modeling) dan mendefinisikan kebutuhan akan sistem yang akan dibuat (requiretments).

\section{Elaboration(Perluasan/Perencanaan)}

Tahap ini lebih difokuskan pada perencanaan arsitektur sistem. Tahap ini juga dapat mendeteksi apakah arsitektur sistem yang diinginkan dapat dibuat atau tidak.Mendeteksi risiko yang mungkin terjadi dari arsitektur yang dibuat.Tahap ini lebih pada analisis dan desain sistem serta implementasi sistem yang fokus pada purwarupa sistem (prototype).

\section{Construction (Konstruksi)}

Tahap ini fokus pada pengembangan komponen dan fitur-fitur sistem. Tahap ini lebih pada implementasi dan pengujian sistem yang fokus pada implementasi perangkat lunak pada kode program. Tahap ini menghasilkan produk perangkat lunak dimana menjadi syarat dari Intial Operational Capability Milestone atau batas/tonggak kemampuan operasional awal.

\section{Transition (Transisi)}

Tahap ini lebih pada deployment atau instalasi sistem agar dapat dimengerti oleh user. Tahap ini menghasilkan produk perangkat lunak dimana menjadi syarat dari Initial Operational Capability Milestone atau batas/tonggak kemampuan operasional awal. Aktivitas pada tahap ini termasuk pada pelatihan user, pemeliharaan dan pengujian sistem apakah sudah memenuhi harapan user. 


\subsection{Sistem Informasi}

Menurut Tata Sutabri (2012,p.46) Sistem Informasi adalah suatu sistem di dalam suatu organisasi yang mempertemukan kebutuhan pengolahan transaksi harian yang mendukung fungsi operasi organisasi yang bersifat manajerial dengan kegiatan strategi dari suatu organisasi untuk menyediakan kepada pihak luar tertentu dengan laporan- laporan yang diperlukan.

\subsection{Unified Modeling Language (UML)}

Menurut Verdi Yasin, S.Kom.,M.Kom (2012,p.194) mendefinisikan Unified Modelling Language (UML) adalah sebuah "bahasa" yang telah menjadi standar dalam industri untuk visualisasi, merancang dan mendokumentasikan sistem piranti lunak, $U M L$ menawarkan sebauh standar untuk merancang model sebuah sistem. Tujuan Penggunaan $U M L$ yaitu untuk memodelkan suatu sistem yang menggunakan konsep berorientasi objek dan menciptakan bahasa pemodelan yang dapat digunakan baik oleh manusia maupun mesin.

Menurut Verdi Yasin S.Kom.,M.Kom(2012,p.268) tipe-tipe Diagram UML adalah sebagai berikut :

a. Use Case Diagram

Use Case Diagram adalah gambar dari beberapa atau seluruh aktor dan use case dengan tujuan yang mengenali interaksi mereka dalam suatu sistem. Use case diagram menggambarkan fungsionalitas yang diharapkan dari sebuah sistem, yang ditekankan adalah "apa" yang diperbuat sistem, dan bukan "bagaimana". Sebuah use case mempresentasikan sebuah interaksi antara actor dan sistem.

b. Activity Diagram

Activity diagram menggambarkan rangkaian aliran dari aktifitas, digunakan untuk mendeskripsikan aktivitas yang dibentuk dalam suatu operasi sehingga dapat juga digunakan untuk aktifitas lainnya seperti use case atau interaksi. Activity Diagram berupa flowchart yang digunakan untuk memperlihatkan aliran kerja dari sistem.

c. Sequence Diagram

Sequence diagram menggambarkan kolaborasi dinamis antara sejumalah dan untuk menunjukkan rangkaian pesan yang dikirim antar objek juga interaksi antar objek, sesuatu yang terjadi pada titik tertentu dalam eksekusi sistem. Sequence diagram menjelaskan interaksi objek yang disusun berdasarkan urutan waktu. Dalam sequence diagram terdapat dua simbol yaitu Actor (untuk menggambarkan pengguna system) dan Lifeline (untuk menggambarkan kelas dan objek).

d. Class Diagram

Class diagram menggambarkan struktur data dan deskripsi class, package dan objek beserta hubungan satu sama lain. Class diagram berfungsi untuk menjelaskan tipe dari objek sistem dan hubungannya dengan objek yang lain.

\subsection{Black BoxTesting}

Menurut Rosa A.S \& M. Shalahuddin (2013,p.275) black box testing adalah pengujian perangkat lunak dari segi spesifikasi fungsional tanpa menguji desain dan kode program. Pengujian dimaksudkan untuk mengetahui apakah fungsi-fungsi, masukan, dan keluaran dari perangkat lunak sesuai dengan spesifikasi yang dibutuhkan.

Pengujian black box dilakukan dengan membuat kasus uji yang bersifat mencoba semua fungsi dengan memakai perangkat lunak apakah sesuai dengan spesifikasi yang dibutuhkan. Kasus uji yang dibuat untuk melakukan pengujian black box harus dibuat dengan kasus benar dan kasus salah, misalkan untuk kasus proses login maka kasus uji yang dibuat adalah : 
a. Jika user memasukkan nama pemakai (username) dan kata sandi (password) benar.

b. Jika user memasukkan nama pemakai (username) dan kata sandi (password) yang salah, misalnya nama pemakai benar tetapi kata sandi salah, atau sebaliknya, atau keduanya salah.

\section{METODOLOGI}

\subsection{Metode Pengembangan Sistem}

Metode pengembangan sistem yang digunakan dalam penelitian ini menggunakan fase RUP (Rational Unified Process). Rational Unified Process adalah salah satu proses perekayasaan perangkat lunak yang mencakup keseluruhan siklus hidup pengembangan perangkat lunak dengan mengumpulkan berbagai latihan terbaik yang terdapat dalam pengembangan perangkat lunak Object Oriented Programming.

Pengembangan sistem menggunakan metode $R U P$ di bagi menjadi 4 fase yaitu:

1. Fase Inception (Permulaan)

Fase inception dapat dikatakan sebagai tahap analisis terhadap penelitian yang dilakukan. Pada tahap ini dilakukan identifikasi masalah sistem lama dan menganalisis kebutuhan untuk sistem baru menggunakan use case diagram.

2. Fase Elaboration (Perluasan/Perencanaan)

Pada tahapan ini dilakukan kegiatan analisis permasalahan, analisis kebutuhan, analisis kelayakan, analisis teknis. Fase ini menekankan tahap desain sistem secara menyeluruh, dan sebagai acuan pembuatan program di fase construction. Selain itu dibuat alur logika sistem yang dituangkan pada activity diagram, kemudian dilakukan perancangan-perancangan seperti merancang class diagram, sequence diagram, design input dan output, dan membuat rancangan tampilan antar muka.

\section{Fase Construction (Kontruksi)}

Pada tahap ini dilakukan pemeriksaan terhadap tahap inception dan elaboration.Tahap ini fokus pada pengembangan komponen dan fitur-fitur sistem, implementasi dan pengujian sistem yang fokus pada implementasi perangkat lunak dan kode program. Dalam pembuatan sistem ini menggunakan php untuk menampilkan rancangan interface dan didalamnya menggunakan coding program agar tampilan interface tersebut dapat menjalankan fungsinya dan mysq yang digunakan sebagai database yang menampung semua data-data yang di inginkan melalui interface pengguna.

\section{Fase Transition (Transisi)}

Fase ini merupakan fase akhir dalam metode pengembangan sistem, yang menjelaskan tentang aktivitas pelatihan penggunaan sistem yang telah dibuat kepada calon pengguna sistem, pemeliharaan sistem dan pengujian sistem apakah sudah memenuhi harapan pengguna dan harapan prodi SI IIB Darmajaya Bandar Lampung. 


\section{HASIL DAN PEMBAHASAN}

\subsection{Analisis Sistem}

Setelah melakukan pengumpulan data yang telah di analisa pihak Prodi SI IIB Darmajaya hanya mengandalkan fasilitas papan pengumuman untuk menyampaikan informasi kepada mahasiswa, alumni dan dosen. Kendala yang dihadapi adalah belum terdapatnya media untuk menampung informasi prodi SI IIB Darmajaya. Pada gambar 2 adalah Arsitektur kerja pada prodi SI IIB Darmajaya sebagai berikut :

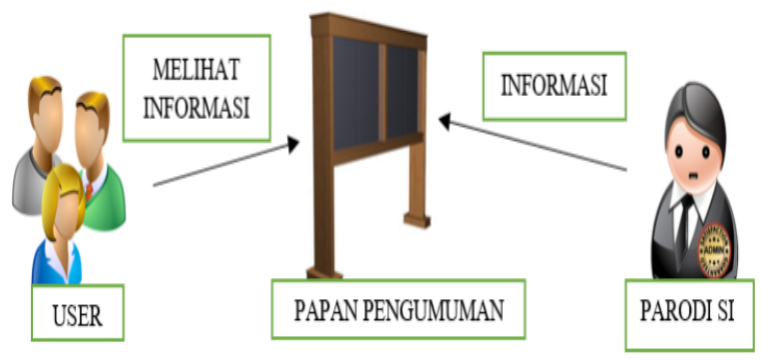

Gambar 2 Arsitektur Kerja Sistem Yang Sedang Berjalan

\subsection{Perancangan Sistem}

\subsubsection{Use Case User}

Penulis mengusulkan untuk membuat rancangan sistem website prodi SI IIB Darmajaya Bandar Lampung yang nantinya dapat diakses kapanpun dan dimanapun oleh pengguna melalu perangkat personal computer $(P C)$ ataupun melalui perangkat komunikasi Smartphone. Untuk rancangan use case diagram website untuk user, maka dapat dilihat pada gambar 3 berikut :

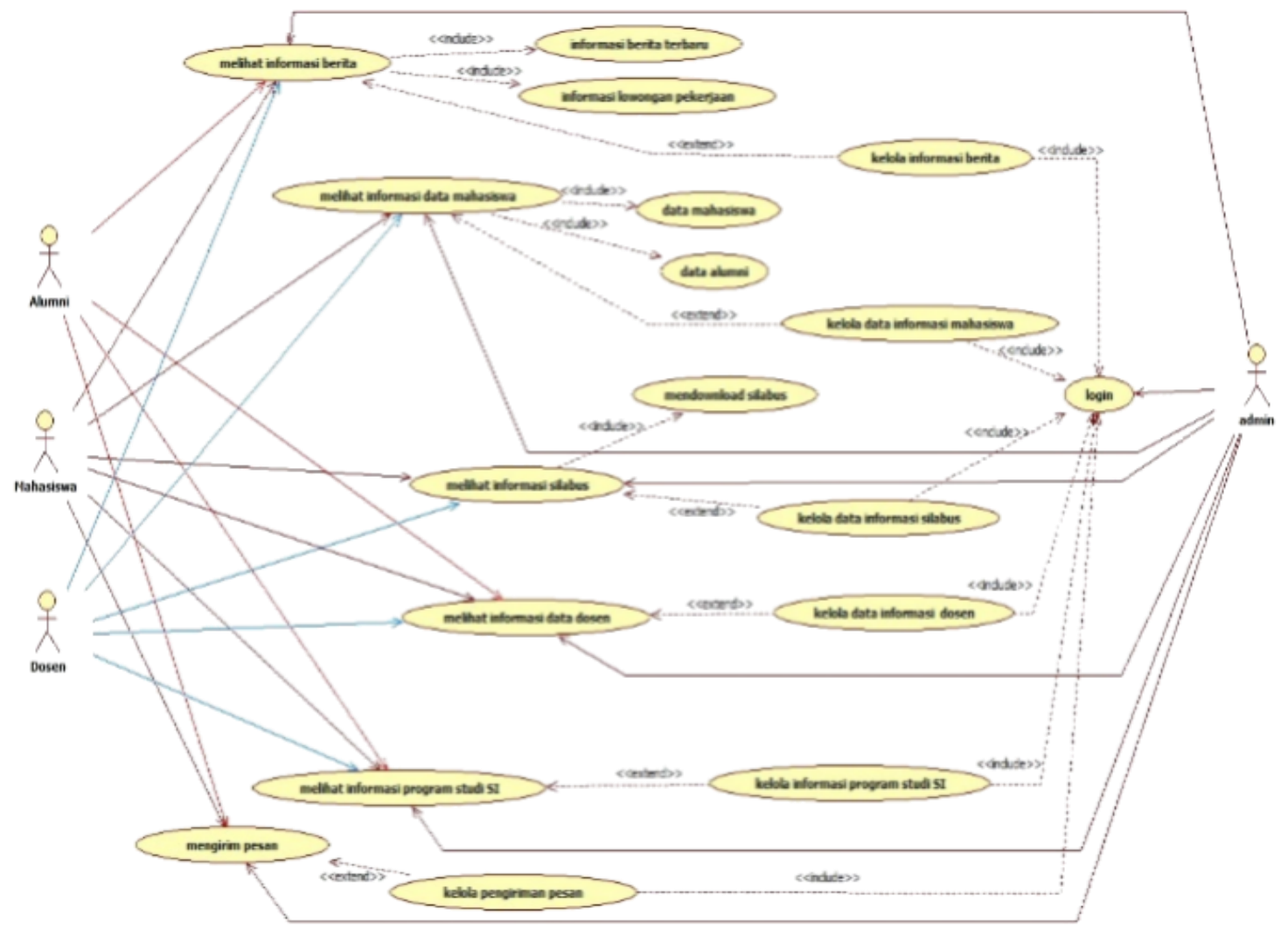

Gambar 3 Sistem use caseUser Yang Diusulkan 


\subsubsection{Activity Diagram Sistem User}

Pada activity diagram sistem user website informasi prodi IIB Darmajaya untuk melihat informasi yang di usulkan. Mulai dari membuka dan melihat halaman website prodi SI hingga mengunduh informasi silabus seperti gambar 4 dan 5 berikut :

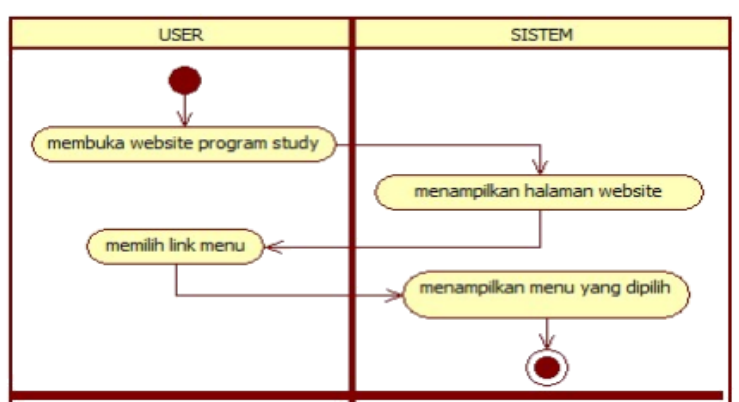

Gambar 4 Activity Diagram Sistem User Yang Diusulkan

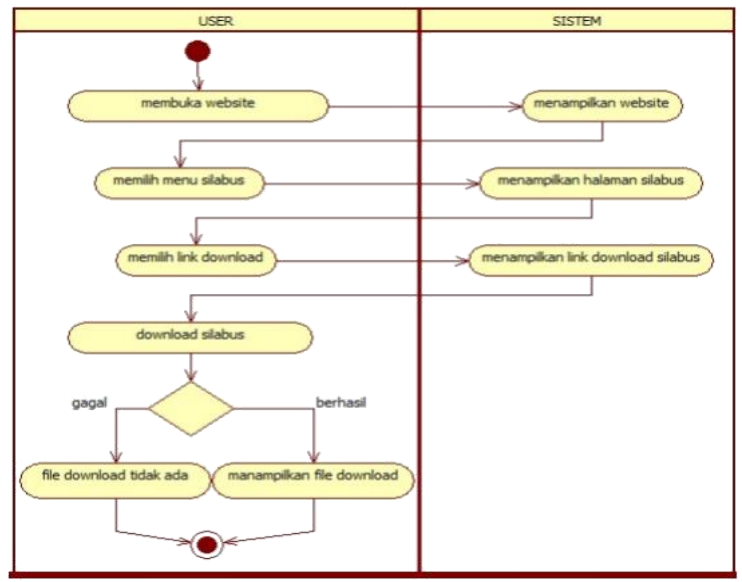

Gambar 5 Activity Diagram Sistem User Melakukan Pengunduhan

\subsubsection{Sequence DiagramSistem User Melihat Dan Mengunduh Informasi}

Pada sequnce diagram gambar 6 menerangkan serangkaian hubungan yang terjadi antara user dan menu utama serta sistem database, pada diagram ini user memilih menu pada menu utama yang sudah disediakan dan dari database akan menampilkan informasi sesuai dengan menu yang dipilih.

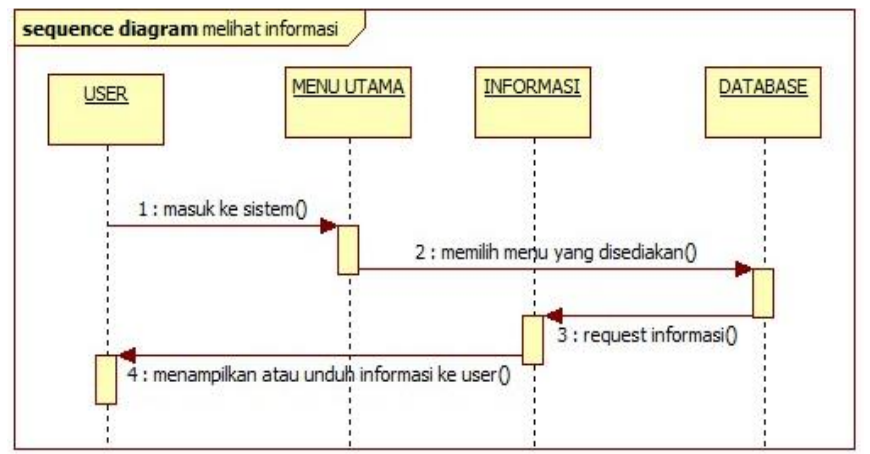

Gambar 6 Sequence DiagramUser Untuk Melihat Yang Diusulkan 


\subsubsection{Class Diagram}

Class diagram merupakan alat bantu untuk menentukan langkah - langkah kerja yang akan dilakukan oleh pemrogram di mulai dari proses pengumpulan data, sampe pembentukan tabel sesuai dengan permasalahan yang ditangani. Class diagram ini terlebih dahulu dirancang dalam mendukung rancangan pengolahan data elektronis supaya dapat berjalan dengan baik, dan dengan relasi yang baik akan diperoleh gambaran umum sistem yang akan dipersiapkan. Untuk lebih jelasnya tentang rancangan class diagram pada website prodi SI IIB Darmajaya dapat dilihat pada gambar 7 berikut :

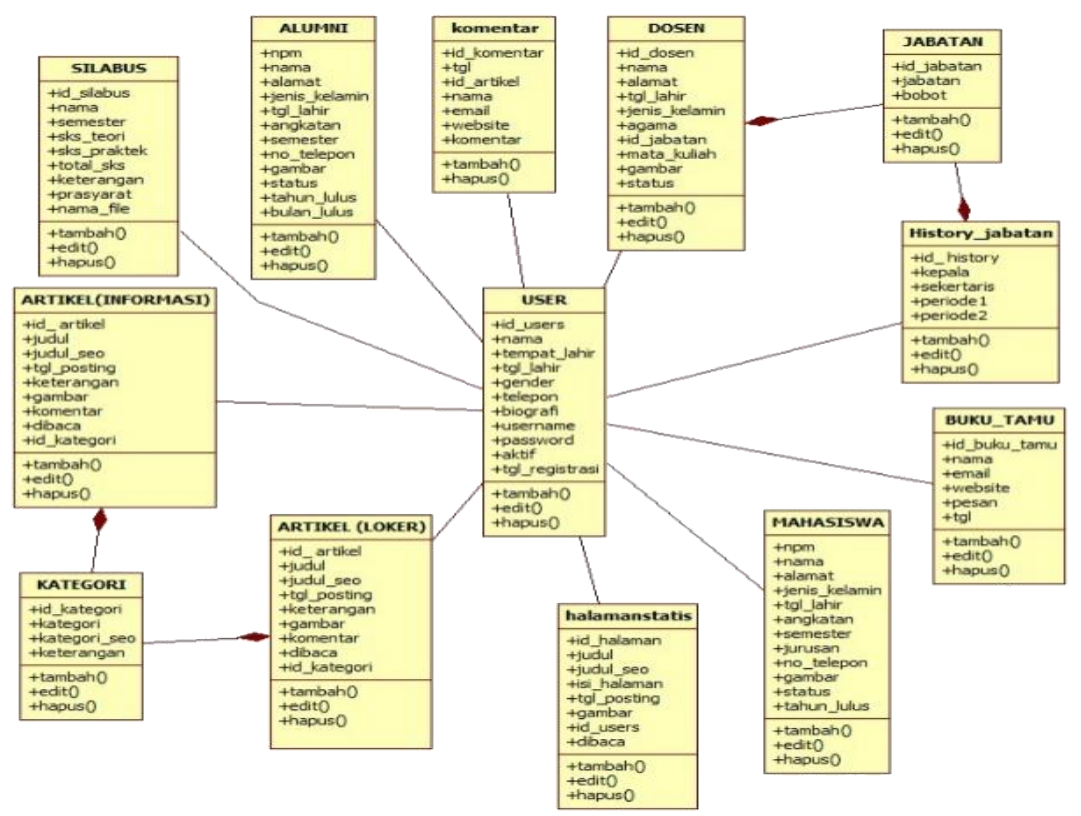

Gambar 7 Class Diagram Sistem Yang Di Usulkan

\subsection{Implementasi Dan Pembahasan}

Pada tahap ini aplikasi yang telah di rancang akan diimplementasi kedalam bahasa pemograman sehingga menghasilkan sebuah perangkat lunak. Adapun perangkat lunak yang digunakan dalam pembuatan aplikasi prodi SI IIB Darmajaya adalah dreamweaver dan notepad ++ , aplikasi ini dibangun pada komputer dengan menggunakan sistem oprasi windows 8 .

\subsubsection{Tampilan Utama Website}

Halaman ini adalah halaman yang akan muncul pada saat pertama kali membuka website, pada halaman ini terdapat тепи уaitu home, berita (informasi dan lowongan pekerjaan), mahasiswa (mahasiswa dan alumni), dosen (data dosen dan struktur dosen), silabus, tentang kami, kontak kami. Penjelasan tentang masing-masing fungsi telah dijabarkan pada $s u b$ bab sebelumnya. Tampilan halaman utama website dapat dilihat pada gambar 8 berikut : 


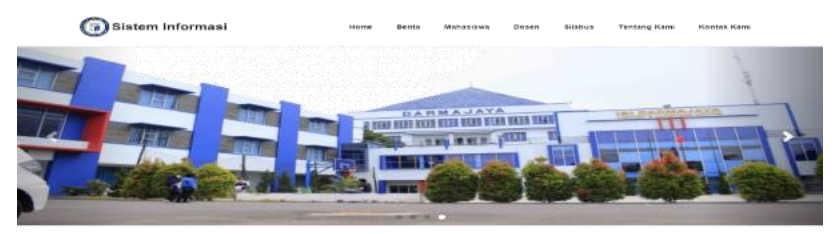

Sistem Informasi | IBI Darmajaya

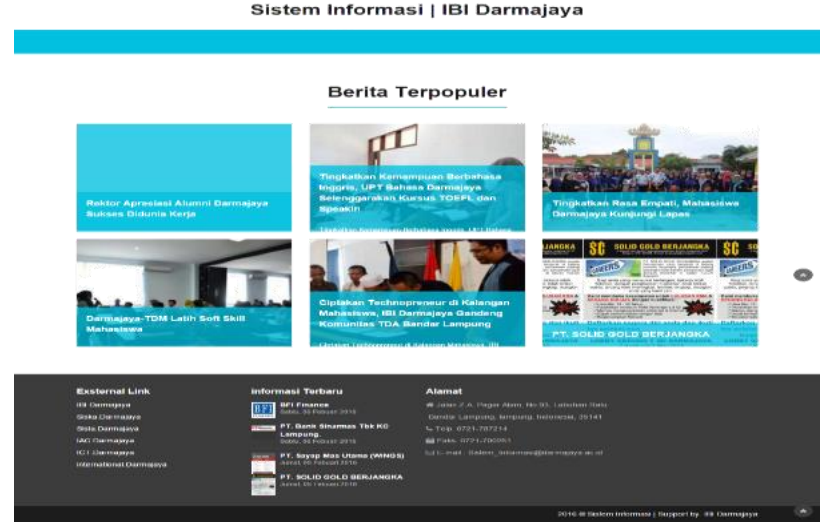

Gambar 8 Halaman Website Utama

\subsubsection{Pengujian}

Pada tahap ini dilakukan pengujian terhadap website prodi SI IIB Darmajaya dengan metode black box testing. Metode black box testing merupakan pengujian program yang mengutamakan pengujian terhadap kebutuhan fungsi dari suatu program dengan menemukan kesalahan fungsi pada program.Pengujian ini dilakukan dengan menguji validasi pada program input admin website dan juga pengujian pada sistem interface yang responsive sehingga dapat menghasilkan output yang sesuai dengan kebutuhannya.

\subsubsection{Pengujian Halaman Menu Data Dosen}

Berikut ini adalah pengujian black box halaman Admin Data Dosen. Pengujian yang dilakukan adalah melihat apakah fungsi-fungsi yang ada pada menu informasi berjalan sesuai perancangan. Pengujian yang dilakukan adalah sebagai berikut :

1. Skenario pengujian : Mengosongkan semua inputan pada form Data Dosen.

Test Case :
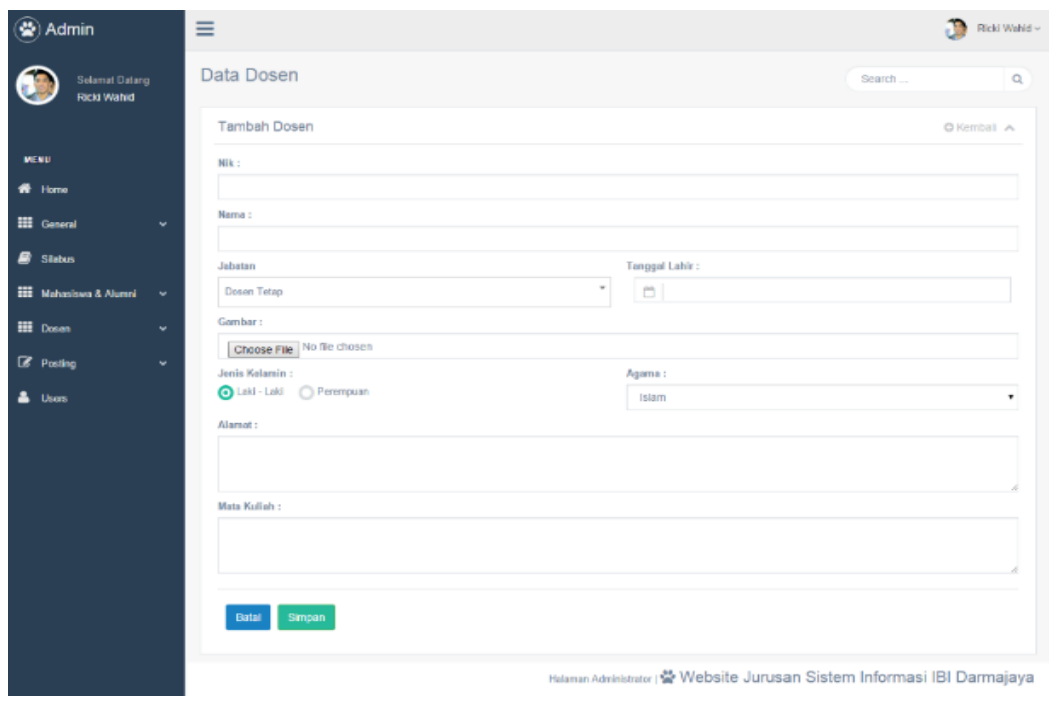

Gambar 9 Skenario 1

Pengujian Halaman Admin Data Dosen 
Hasil yang diharapkan : Sistem akan menolak dan menampilkan "input tidak boleh kosong". Hasil pengujian :
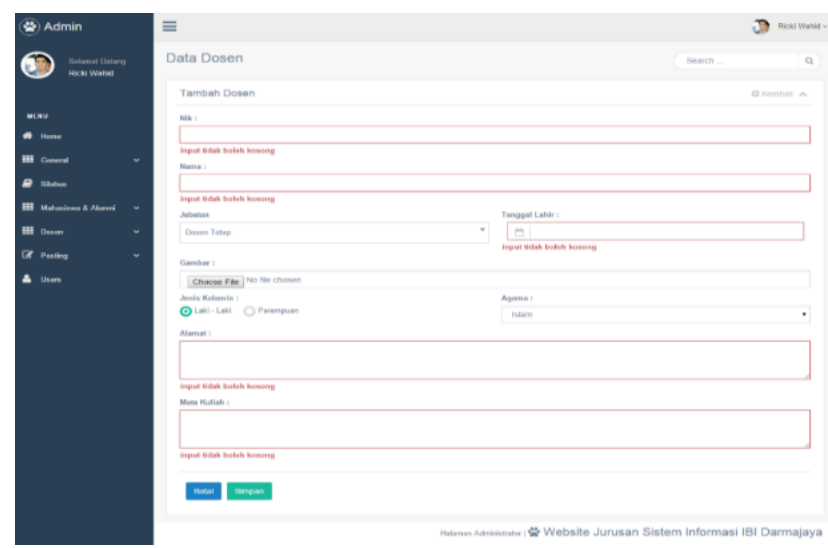

Gambar 10 Hasil Skenario 1 Pengujian Halaman Menu Data Dosen

Kesimpulan : Valid

\subsubsection{Pengujian Tampilan Interface Program Data Dosen}

Berikut ini merupakan pengujian terhadap tampilan atau interface program yang responsive atau dapat mengikuti layar atau resolusi dari perangkat yang dipakai. Pengujian tampilan program yaitu sebagai berikut.

1. Skenario Pengujian : Membuka program di personal computer.

Hasil yang diharapkan $\quad$ : Program akan menampilkan sesuai dengan ukuran layar personal computer.

Hasil pengujian:

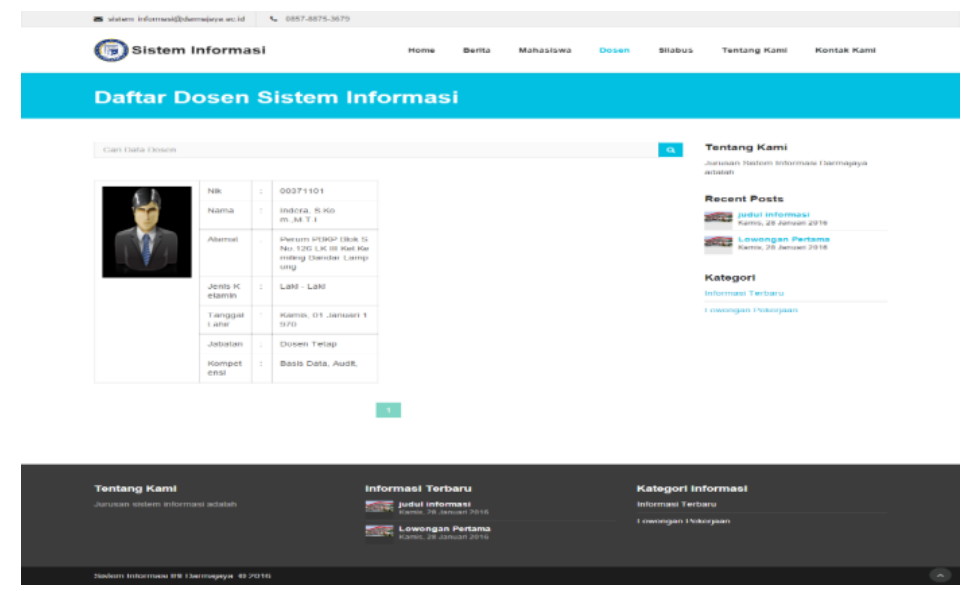

Gambar 11 Pengujian Tampilan Interface Program Data Dosen Pada PC

Keterangan : Valid 


\section{KESIMPULAN}

Berdasarkan pembahasan sebelumnya maka dapat disimpulkan bahwa :

1. Website ini akan memberikan informasi kepada Mahasiswa, Alumni dan Dosen dengan cepat dan akurat, untuk mengetahui tentang semua informasi yang berhubungan dengan Prodi SI.

2. Website ini memudahkan Mahasiswa, Alumni dan Dosen dalam mengaksesnya, karena dapat diakses melalui perangkat personal computer dan smartphone yang tersambung ke jaringan internet serta tidak terbatas ruang dan waktu.

3. Keamanan data sepenuhnya dipegang oleh admin website Prodi SI.

\section{DAFTAR PUSTAKA}

A.S Rossa \& Shalahuddin, M., 2013. Rekayasa Perangkat Lunak Terstruktur Dan Berorentasi Objek. Bandung. Penerbit Informatika

Kurniawan, Hendra. 2013. Analisis Dan Desain Berorentasi Objek. Lampung. IIB Darmajaya

Kustiyaningsih, Y \& Anamisa, D.R. 2011.Pemograman Basis Data Berbasis Web Menggunakan PHP \& MySQL. Jogyakarta. Penerbit Graha Ilmu

Sutabri, Tata. 2012. Konsep Sistem Informasi. Jogyakarta. Penerbit Andi

Yasin, Verdi. 2012. Rekayasa Perangkat Lunak Berorentasi Objek. Jakarta. Penerbit MitraWacana http://www.darmajaya.ac.id. Diakses pukul 23:00 : 26-11-2015 